\title{
Characteristics of Broiler Chicken Meat Given with Fermented Bean Sprouts Ration
}

\author{
Ni Ketut Sri Rukmini ${ }^{*}$, Ni Ketut Mardewi ${ }^{2}$, G Gusti Ayu Dewi Seri Rejeki ${ }^{3}$ \\ ${ }^{1}$ Animal Husbandry Department, Faculty of Agriculture, Universitas Warmadewa, Denpasar, Bali- \\ Indonesia \\ \{srirukmini9999@gmail.com¹
}

\begin{abstract}
Broiler Chickens are a contributor to protein for humans. In the maintenance of broilers, the cost of feed can reach $60-70 \%$ and the total cost of production so that alternative feeds are needed which are cheap, easy to obtain and contain good nutrition. The use of bean sprouts waste in rations, the protein content is quite high, but the crude fiber is also high, so it is necessary to carry out fermentation to increase digestibility. The characteristics of meat can change due to impaired nutritional digestion. The purpose of this study was to determine the characteristics of broiler chicken meat fed fermented bean sprouts rations. This study used a complete equipment design (CRD). The results showed that the provision of rations added with fermented bean sprouts flour had an insignificant difference $(\mathrm{P}>0.05)$ on water content. $\mathrm{pH}$, cooking losses, water holding capacity and meat color. Based on the results of the study, it can be concluded that the differences in the treatment given did not affect the characteristics of broiler chicken meat and fulfilled the meat quality classification standards.
\end{abstract}

Keywords: Broiler Chicken; Characteristics of Meat; Fermented Bean Sprouts

\section{Introduction}

Broilers, also known as commercial broilers, are among the superior breeds of crosses from several chickens that have high productivity, especially in producing chicken meat. Broilers are a source of contributing to the needs of animal protein for the community. The specialty of broilers is that they have the ability to produce meat with not so long maintenance time.

Some of the obstacles that are often faced by breeders in maintaining broiler chickens are the cost of feed. [1] stated that feed costs account for $60-70 \%$ of total production costs. To reduce high feed costs, innovative efforts are needed to utilize alternative feed ingredients which are cheap and easy to obtain and have good nutritional content [2]. One way that can be done is by utilizing waste that can still be used as animal feed, such as market waste.

Of the several types of market waste, one of the market wastes that can be used as animal feed is bean sprouts. The waste of bean sprouts comes from the residual processing of bean sprouts which can be used as feed for broiler chickens. Sprouts waste has several weaknesses, namely crude fiber such as high hemaglutimin, namely $49.44 \%$ which is a compound that is toxic when given to livestock [3].

This is in accordance with the opinion [4] which states that high crude fiber needs to be limited in its use in the ration, because poultry has limitations in digesting crude fiber. One 
way to overcome this problem, by increasing the nutritional value of the ration, namely by reducing high crude fiber and increasing digestibility is to carry out fermentation [5]. Fermentation is a processing of bean sprouts skin with the help of enzymes from a microorganism. In the fermentation process, complex compounds are converted into simpler compounds. Fermentation aims to increase nutritional content, reduce anti-nutritional substances, increase the digestibility of livestock and increase the storage time of the bean sprouts skin product.

In Indonesia, the quality standard of chicken carcass is regulated in SNI 3924: 2009. This standard specifies the classification, quality requirements, cut of carcass, packaging, labeling and storage of carcass and broiler meat. In developed countries, consumers are very concerned about the quality and characteristics of the meat to be consumed, so that meat with good quality and characteristics will have a higher selling value.

From the description above, it is necessary to conduct research on the characteristics of broiler chicken meat fed fermented bean sprouts waste ration.

\section{Method}

\subsection{Location and Length of Research}

Research on raising broiler chickens was carried out at the Experimental Station of the Faculty of Agriculture, Warmadewa University and the characteristics of broiler chicken were carried out in the Basic Sciences Laboratory of the Faculty of Agriculture, Warmadewa University, which is located in Tanjung Bungkak, Sumerta Village, East Denpasar District, Denpasar City. The research time starts in May - December 2020.

\subsection{Research Methods}

The research method used was a completely randomized design with 4 treatments and 3 replications for each treatment. The treatment given is as follows.

P0 : Chicken meat that contains rations without fermented bean sprouts

P1 : Chicken meat containing fermented bean sprouts waste ration 3\%

P2 : Chicken meat containing 6\% fermented bean sprouts waste ration

P3 : Chicken meat containing fermented bean sprouts waste ration $9 \%$

\subsection{Materials and Tools}

This study used 100 grams of broiler breast meat. The materials used were distilled water, benzene petreleum and filter paper. The tools used are a knife, plastic, cutting board, basin, stove, pan, $\mathrm{pH}$ meter, beaker glass, scale, thermometer, stirring rod, porcelain cup, oven, chromameter.

\subsection{Observed Variables}

The parameters observed were $\mathrm{pH}$, moisture content, cooking losses, water holding capacity, and color.

\subsection{Statistic Analysis}

The data obtained were analyzed by means of analysis of variance, if there were significantly different results $(\mathrm{P}<0.05)$ then it was followed by Duncan's smallest realdistance test [7]. 


\section{Results and Discussion}

In this study, broiler chickens were given rations with rations without containing fermented bean sprouts waste and rations containing fermented bean sprouts waste. Broiler chicken meat according to the treatment was then analyzed in the laboratory of the Faculty of Agriculture with test parameters of moisture content, ash content, $\mathrm{pH}$, weight loss, water binding capacity, color intensity $(\mathrm{L}, \mathrm{a} *, \mathrm{~b} *)$. The test results were then followed by analysis of variance with Anova. Based on the results of statistical analysis, it was found that chicken meat without the addition of fermented bean sprouts flour produced an insignificant difference $(\mathrm{P}>0.05)$ on all treatments for each variable, as shown in Table 1.

Table 1. Characteristics of 5 week old Broiler Chicken

\begin{tabular}{lllll}
\hline \multicolumn{1}{c}{ Treatment } & \multicolumn{1}{c}{ P0 } & \multicolumn{1}{c}{ P1 } & \multicolumn{1}{c}{ P2 } & \multicolumn{1}{c}{ P3 } \\
\hline $\mathrm{pH}$ & $5.46 \mathrm{a}$ & $5.50 \mathrm{a}$ & $5.40 \mathrm{a}$ & $5.42 \mathrm{a}$ \\
Water Binding & $28.25 \mathrm{a}$ & $28.62 \mathrm{a}$ & $27.42 \mathrm{a}$ & $27.65 \mathrm{a}$ \\
Shrink Cook & $29.25 \mathrm{a}$ & $27.18 \mathrm{a}$ & $26.30 \mathrm{a}$ & $24.81 \mathrm{a}$ \\
Color L & $38.14 \mathrm{a}$ & $43.96 \mathrm{a}$ & $45.12 \mathrm{a}$ & $40.46 \mathrm{a}$ \\
Color a & $7.22 \mathrm{a}$ & $7.44 \mathrm{a}$ & $6.81 \mathrm{a}$ & $6,07 \mathrm{a}$ \\
Color b & $7.58 \mathrm{a}$ & $10.91 \mathrm{a}$ & $11.32 \mathrm{a}$ & $11.04 \mathrm{a}$ \\
Water content & $74.97 \mathrm{a}$ & $75.32 \mathrm{a}$ & $74.52 \mathrm{a}$ & $73.70 \mathrm{a}$ \\
\hline
\end{tabular}

Information :

- Treatment

P0: Chicken meat containing rations without fermented teuge waste

P1: Chicken meat containing 3\% fermented bean sprouts ration

P2: Chicken meat containing $6 \%$ fermented bean sprouts ration

P3: Chicken meat containing $9 \%$ fermented bean sprouts ration

- The same letter in the same row indicates no significant treatment $(\mathrm{P}>0.05)$

\section{1. pH Value}

PH measurement aims to determine the acidity and alkalinity of food products. The degree of acidity $(\mathrm{PH})$ is one of the requirements to determine one of the characteristics of meat. From the analysis test, the $\mathrm{pH}$ of the research chicken ranged from 5.40 to 5.50. Of the four treatments, there was no effect $(\mathrm{P}>0.05)$ on the $\mathrm{pH}$ value of the meat (Table 4.1). According to [8], the normal $\mathrm{pH}$ value of broiler chicken is between $5.96-6.07$. The $\mathrm{pH}$ value can be related to the water holding capacity and shelf life of meat with a low $\mathrm{pH}(5.1-6.1)$ is preferred to maintain meat quality. A high $\mathrm{pH}$ of around $6.2-7.2$ causes the meat to have a darker color and a more favorable condition for the development of microorganisms. From the research results, the $\mathrm{pH}$ value of the meat was in the normal range.

\subsection{Water Bonding}

The average water binding capacity of the treatment given to broilers aged 5 weeks had no effect on the binding power of meat $(\mathrm{P}>0.05)$ as shown in Table 4.1. Water binding capacity (DMA) will describe the level of damage to meat protein, because meat DMA is the ability of meat protein to bind water in the meat, or the ability of meat to hold water as long as there are forces influences such as meat cutting, heating, grinding and pressure. Water binding power is one of several characteristics of meat which is very important for shaping the quality of meat. Meat that is able to bind high water is classified as good quality meat, meat with low water binding power will lose a lot of fluids, resulting in weight loss. 
The mean water binding capacity (DMA) of the meat from the study ranged from $27.42 \%$ to $28.62 \%$. According to [9] The water binding power of broiler chickens aged 6-7 weeks was around $22.19 \%$ to $28.54 \%$, while [10] stated that the water binding power of broilers ranged from $20 \%$ to $60 \%$. From the research results, the average binding power of meat was in the normal range. [9] stated that the binding capacity of water is also influenced by the $\mathrm{pH}$ of the meat, a high $\mathrm{pH}$ value can improve the binding power of water, on the other hand, a low $\mathrm{pH}$ value causes the structure of the meat to open, thereby reducing the binding power of water.

\subsection{Cooking Shrinkage}

Shrinkage of meat is an important determinant of chicken meat quality, because it is related to the amount of water lost and nutrients that dissolve in water due to the effect of cooking. The lowest cooking loss of chicken meat results in treatment P3 (9\% TLTF) was not significantly different from other treatments (P0, P1, P2). The cooking loss results were relatively the same, related to water binding capacity and the $\mathrm{pH}$ of the study which were also not significantly different $(\mathrm{P}>0.05)$. Water binding capacity has a positive relationship with the $\mathrm{pH}$ value of the meat and the percentage of cooking loss. This is supported by [11] that, cooking losses are influenced by the $\mathrm{pH}$ of the meat which has a low water binding capacity, it will lose a lot of liquid, resulting in a decrease in meat weight. From the research results, the range of cooking losses between $24.81 \%$ and $29.25 \%$. According to [12], cooking losses vary between $15 \%$ - 54\%. Good quality meat has low cooking losses, because the loss of nutrients during cooking will be less, heating and boiling will reduce cooking losses of food, due to reduced or loss of moisture content in these foods [10].

\subsection{Color}

Color is an important factor in acceptance and rejection of food products for consumption and can affect quality. Color changes will indicate changes in nutritional value, so that the color is used as an indicator of the level of maximum nutritional value received. The color of chicken meat is influenced by many factors, including age, gender, feed, fat, water content, conditions before being slaughtered to processing. The color of chicken meat is caused by vitamin A which is found in meat fat and the pigment oxymyoglobin. Oxymoglobin pigment is an important pigment in fresh meat, this pigment is only present on the surface and describes the meat color that consumers want. The color of chicken meat due to imperfect blood loss is caused by the pigment myoglobin [13].

Color testing is carried out objectively using a photoelectric colorimeter called a Hunter Colorimeter. The Hunter color notation system is characterized by the three parameters $\mathrm{L} *$, a $*$, and $\mathrm{b} * \mathrm{~L} *$ values range from $0-100$ from black to white. The higher the $\mathrm{L} *$ value, the higher the degree of vaginal discharge. The $\mathrm{a} *$ and $\mathrm{b} *$ values are between positive and negative values. For $\mathrm{a} *$ shows the degree of green $\left(\mathrm{a}^{*}-\right)$ to red $(\mathrm{a} *+)$, while $\mathrm{b} *$ shows the degree of yellow $\left(b^{*}+\right)$ to blue $\left(b^{*}-\right)$ [30]. Based on the results of meat color testing on all meat samples at the $\mathrm{L} *$ (brightness) value in all treatments, the values were not significantly different $(\mathrm{P}>0.05)$ with an average value ranging from 38.14 to 45.12 . The a * value (redness) has an average that is not significantly different $(\mathrm{P}>0.05)$ with all treatments with values ranging from 6.07 to 7.44 , and the $\mathrm{b} *$ (yellowish) value also has a value that is not significantly different with values ranging from 7.58 to 11.32 . This shows that the treatment of fermented bean sprouts waste does not affect the color of broiler chicken meat. The color of fresh chicken meat is yellowish white, this is in accordance with the statement [14], that the color of chicken meat is due to provitamin A contained in meat fat and the pigment oxymyoglobin [13], stating that the oxyyoglobin pigment is an important pigment in fresh 
meat, this pigment is only exist on the surface and describe the color of meat that consumers want.

\subsection{Moisture Content}

Water content is a very important characteristic of food, because water can affect the appearance, texture and taste of food ingredients. High water content makes it easy for bacteria, mold and yeast to reproduce so that changes in food material occur.15]. The water content of the research meat ranged from $73.70 \%$ to $75.32 \%$. The water content contained in the meat in treatment P1 (3\% TLTF) showed a higher yield was not significantly different (P> 0.05 ) to treatment $\mathrm{P} 2$ level $6 \%$ (meat moisture content $73.70 \%$ ), P0 control (value content meat water $74.97 \%$ ) and $\mathrm{P} 3$ level $9 \%$ (water content value $73.70 \%$ ).

[16] that the moisture content of broiler chicken is $65 \%-80 \%$, this means that the water content of the research meat is still at normal limits. The water content in meat is influenced by the intramuscular fat content contained in the muscles, if the water content falls, the cooking losses will decrease, the low cooking losses will provide the high yield needed in meat processing [17]. It is supported [18] that carcass quality is related to age and high intramuscular fat tends to have high water content.

\section{Conclusion}

The differences in the treatment given to the maintenance of broiler chickens up to 5 weeks of age do not affect the characteristics of broiler chicken meat, so that it can be classified as meat that meets the meat quality classification standards.

\section{Acknowledgments}

The author would like to thank the Chairman of the Korpri Welfare Foundation of Bali Province, Rector of Warmadewa University, the Head of the Warmadewa University Research Institute, the Dean of the Faculty of Agriculture and colleagues who have provided all support in completing this research.

\section{References}

[1] N. J. Daghir, "Poulty Production is Hot Climate 2" ," United Kingdom: University Press Cambrige, 1997.

[2] A. N. Sari, "Total solid ingredients, protein content, and favorite value of mozzarella cheese from the combination of buffalo milk and cow's milk," $J$. of Food Technology Applications. vol. 3, vol. 4. pp152-156, 2014.

[3] S. Rahayu, D. Diapari, D. S Wandito, and W. W. Ifafah, "Survey of Potential Availability of Tauge Waste as Alternative Animal Feed in Bogor Municipality" Bogor: Bogor Agricultural University, 2010.

[4] T. Sutardi, "Basis of Nutrition Science" Faculty of Animal Husbandry, Bogor Agricultural University, 2009. 
[5] BPTP (Research and Development Research Agency), "Save cost making poultry feed with agro-industrial waste," Yogyakarta, 2009.

[6] M. Y. Surung, "Effect of EM4 dosage in drinking water on body weight of native chickens." J. of Agrosystem, vol. 4, no. 2, pp.25-30, 2008.

[7] G. D. Stell, and J. H. Torrie, "Principles and Procedures of Statistics". Jakarta: Gramedia Pustaka Utama, 1993.

[8] R. Van-Laack, C. H. Liu, M. Smith, and H. Loveday, "Characteristics Of Pale, Soft, Exudative Broiler Breast Meat," Poult Sci, vol. 79, no 7, pp.1057-1061, 2000.

[9] C. Alvarado, and S. Mc Kee, "Marination To Improve Functional Properties And Safety Of Poultrymeal. J of Applypoutry Res, vol. 16, pp.113-120, 2007.

[10] Soeparno, "Meat Science and Technology prints the $5^{\text {th }}$," Yogyakarta: Gajah Mada University Press, 2009.

[11] Hartono, E. N Iriyanti, and R. S. S Santosa, "The Use Of Functional Feed On Water Holding Capacity, Cooking Losses, And Tenderness Of Broiler Chicken," Animal Science Journal. vol. 1. no 1, pp.10-19, 2013.

[12] D. Winarso, "Changes in Physical Characteristics Due to Differences in Age, Types of Muscles, Boiling Time and Temperature of Village Chicken Meat," Magelang: Magelang College of Agricultural Extension, pp.119-132, 2003.

[13] R. A. Lawrie, "Meat Science. Fifth Edition. Translators Aminuddin Parakkasi and Yudha Amwila," Jakarta: University of Indonesia (Press), 2003.

[14] R. Indiarto, B. Nurhadi, and E. Subroto, "Study of Texture Profile Analysis and Organoleptic Smoked Chicken Meat Based on Coconut Shell Liquid Smoke Technology," J. of Agricultural Product Technology, vol. 5, no. 2, pp106-116, 2012.

[15] H. R. Cross, "Carcass Science, Milk Science and Technology,". New York: Elsevier Science, 1988.

[16] H. P. Rasyanta, "The Use Of Coconut Shell Smoke In Preserving Milkfish. Department Of Chemistry," Faculty of Mathematics and Natural Sciences, Semarang State University, 2013.

[17] M. Afrianti, B. Dwiloka, and B. E. Setiani, "Total bacteria, pH, and moisture content of broiler chicken meat after soaking with the extract of senduduk leaves (Melastoma malabathricum L.) during the shelf life," J. of Food and Nutrition, vol. 4, no. 7, pp.49-56, 2013.

[18] V. P. Nurwantoro, A. M. Bintoro, A. Legowo, L. D. Purnomoadi, A. Ambara, S. Prokoso, and Mulyani, "pH value, moisture content, and total Escherchia coli of beef marinated in garlic juice,". J. App. Tech. Food. vol. 1, no. 2, pp.20-22, 2012. 